\title{
PREDICTING BANKRUPTCY ON MINING COMPANIES USING ALTMAN Z-SCORE MODEL (EMPIRICAL STUDY ON MINING COMPANIES LISTED IN INDONESIAN STOCK EXCHANGE YEAR 2014-2015)
}

\author{
Husnul Akhir ${ }^{* 1}$, Islahuddin ${ }^{2}$ \\ ${ }^{1,2}$ Program Studi Akuntansi Fakultas Ekonomi dan Bisnis Universitas Syiah Kuala \\ e-mail: husnulakhir@yahoo.com ${ }^{* 1}$, islahuddin@ unsyiah.ac.id ${ }^{* 2}$
}

\begin{abstract}
The aim of this study is to calculate Altman Z-Score to predict the possibility of bankruptcy of mining companies listed in Indonesia stock exchange based on the information from the annual financial statementwith observation ranging from 2014 until 2015. The type of data used is secondary data. The study employed Altmant Z-Score calculation on a targeted population of 22 mining companies listed on the Indonesia Stock Exchange.The analysis technique used is the prediction model of bankruptcy Altman Z-score. Using the formula Z-Score $=1,2 X 1+1,4 X 2+3,3 X 3+0,6 X 4+$ 1,0X5, where $X 1$ represents the ratio of liquidity, $X 2$ and $X 3$ as profitability ratios, and $X 4$ and $X 5$ are activity ratios. Then with the use of Z-Score assessment criteria $>2.99$ categorized as a very healthy company. $1.81<Z$-Score $<2.99$ is in the grey area so the possibility of rescue and possibly bankrupt is as great as it depends on the decision of the company management policy as the decision maker. Zscore $<1.81$ is categorized as a company that has very large financial difficulties and high risk so that the possibility of bankruptcy is very large. The results show that in 2014, $55 \%$ of mining companies predicted bankruptcy, $18 \%$ are in grey area and the remaining $27 \%$ of mining companies have a healthy financial condition. Then in 2015, 64\% of mining companies are predicted to go bankrupt, $23 \%$ are in grey area and $13 \%$ of companies are in good condition or not bankrupt.
\end{abstract}

Keywords: Bankruptcy prediction, Possibility of bankruptcy, Altman Z-Score.

\section{Introduction \\ Background}

In accordance with the increasingly integrated economy in the era of globalization, the economic crisis that occurred in a country can easily spread to other countries and become a global financial disaster in a short time. The economic crisis be able to lead to a decline simultaneously on all economic activity such as employment, investation, and corporate profits. In early 2016, International Monetary Fund (IMF) warned of the potential for reoccurrence of the market chaos during the crisis in 2008. According to the IMF, there are two main triggers that caused the world was on the verge of crisis. The trigger is the European economic crisis and China's economic conditions was in a terrible(usatoday.com).

The decline in the growth of the Chinese economy, which began in 2013 have an enormous impact for the world.China is now a country with the largest population in the world which amounts to about 1.4 billion people (bloomberg.com). With the population has been making China one of the world's largest commodities consumer, so that when China suffered a slowing economy certainly importing and exporting of the countries will fall and cause the demand and supply will be reduced as well.

The decline in world oil prices is the impact of the conditions of economic slowdown in China. In early 2015 , world oil prices reach $\$ 47$ per barrel, however at the end of 2015 dropped to USD 37.33 per barrel (nasdaq.com). The fall in the oil price impact on coal markets are also experiencing price declines. Coal is also one of the mining commodities, experienced a decline of demand for low-calorie coal. The fall in coal prices resulted in many coal producers in the world that must be decrease the amount of production even stopped their production activities because of the profit margin are slim. Peabody Energy, the largest coal mining company in the world that which in April 2016 has submitted for bankruptcy protection. Peabody went bankrupt due to being unable to pay its debts on maturity (washingtonpost.com). 
The condition of the declining price of mining commodities also have a bad impact on the Indonesian economy, especially in the mining sector. In early 2016 , the Central Statistics Agency (BPS) publishes the business sectors contributing to Indonesia's Gross Domestic Product during the years 2014-2015.

Tabel 1.1

Various Growth Business in Indonesia

\begin{tabular}{|l|c|c|}
\hline \multirow{2}{*}{ Business Sector } & \multicolumn{2}{|c|}{ Growth Rate } \\
\cline { 2 - 3 } & $\mathbf{2 0 1 4}$ & $\mathbf{2 0 1 5}$ \\
\hline Agriculture, Forestry and Fishery & 4,24 & 4,02 \\
\hline Mining & 0,72 & $-5,08$ \\
\hline Processing Industry & 4,61 & 4,25 \\
\hline Electricity and Gas & 5,57 & 1,21 \\
\hline Water Supply & 5,87 & 7,17 \\
\hline Construction & 6,97 & 6,65 \\
\hline Wholesale and Retail trade & 5,16 & 2,47 \\
\hline Transport and Warehousing & 7,36 & 6,68 \\
\hline Hotel and Restaurant & 5,77 & 4,36 \\
\hline Information and Communication & 10.10 & 10,06 \\
\hline Finance and Insurance Service & 4,68 & 8,53 \\
\hline Real Estate & 5 & 4,82 \\
\hline Soure: BPS (2016) & \multicolumn{2}{|c|}{} \\
\hline
\end{tabular}

Source: BPS (2016)

Based on Table 1.1, it can be seen that Indonesian economic growth throughout the period 2014-2015 occurred in all business sectors except mining. The contraction in the mining sector as well due to the mining commodity prices coming down, the tight of government regulations, and the high royalties become a serious challenge for mining companies. With an increasing number of expenses incurred by the company, while the benefits have not been able to cover the operational costs make the position of Indonesian mining companies increasingly cornered and difficult to develop.

The problems on mining sector has turned into a complex matters. A drastic reduction of the demand for commodities in the market, forcing the companies had to reduce the quantity of production. The mining company previously had conducted a massive loan for business expansion, then many are suffered financial difficulties. Even the companies had to deal with the debts that can not be paid and culminate in bankruptcy.

Starting from the financial difficulties that the term in the mining company that used to indicate the condition of the failure, inability to pay off debts and default. The insolvency in the bankruptcy indicates a negative net worth of a company. The inability to pay off debt showed a negative performance and their liquidity problems. Default means that a company violating an agreement with creditors and be able result in legal action (Atmini and Wuryana, 2005:460). In principle, bankruptcy is simply legal mechanisms that allow creditors to take over the company when a decrease in asset value triggered the failure repayment of existing debts. Bankruptcy is not the cause of a decrease in the value of the company. Bankruptcy is the result of decrease in value of the company (Brealey et al,2008:19).

Bankruptcy can be identified early by using a model of an early warning system. With an early detection of the condition of the company, it is possible for an internal party of the company, investors and creditors undertake anticipative measures to prevent the financial crisis handled immediately (Endri, 2009:36). Analysis of the financial statements could be used to predicting the future, while from a management point, financial statement analysis is used to assist management in anticipate the conditions of financial difficulties later on and become a starting point for planning actions that will influence future events (Brigham and Houston, 2006). 
In analyzing the financial statements, the measurement of the company's bankruptcy can be done by two methods, the method of univariate and multivariate method. According to Hanafi (2004:655), univariate analysis conducted by looking the financial variables that is estimated to affect or associated with the bankruptcy in analyzing separately. Meanwhile, the ratio analysis is one form of univariate, this method is generally used by investors to calculate and analyze a wide variety of financial ratios such as working capital, profitability ratios, debt level or leverage, and liquidity to detect signs of the bankruptcy of a company, however a problem arises that respectively have utility ratios and give different indications regarding the financial health of the company. Occasionally these ratios was also seen opposite each other. Therefore, if it is just relying on ratio calculation individually then the investor would have difficulties and confusion for deciding whether the company is in a healthy condition or vice versa. However, multivariate analysis using two or more variables simultaneously in a single equation (Hanafi, 2004:656).

Altman Z-Score model is a multivariate discriminant analysis (MDA) developed by Edward I. Altman for predicting corporate bankruptcies (Grice and Ingram, 2001). MDA is a statistical technique used to classify an observation into one of several a priori groupings dependent upon the observation's individual characteristics (Altman, 1968). To develop the Z-Score model, Altman (1968) compiled a list of 22 financial ratios and classified each into one of five categories, liquidity, profitability, leverage, solvency, and activity. The ratios were not selected on a theoretical basis, but rather, on the basis of their popularity in the literature and Altman's belief about their potential relevancy to bankruptcy. By estimating the model using MDA to derive a linear combination of variables that discriminated between 33 bankrupt and 33 nonbankrupt firm, the research has accuracy quite high at 95\% in predicting corporate bankruptcies (Grice and Ingram, 2001).

Consider the phenomenom and facts about the need to perform a measurement of the company's financial condition the bankruptcy prediction analysis, especially in the mining company because given that the global and domestic economic conditions existing on a situation of uncertainty may directly affect the stability of the company. Based on the absence of any research on bankruptcy prediction that examines the the condition of mining company in a period of global economic crisis, the research like this to be interesting to study. Then, the authors decided to conduct a study that aims to examine the Predicting Bankruptcy on Mining Companies Using Altman Z-Score Model listed in Indonesia Stock Exchange year 2014-2015.

\section{Research Objectives}

Based on the research problem, the objectives of this research is to calculate Altman Z-Score to predict the possibility of bankruptcy of mining companies listed in IDX year 2014-2015.

\section{Literature Review \\ Bankruptcy}

Bankruptcy is usually a condition in which a company can no longer afford to operate the company with either due to financial difficulties experienced by these entities has been very severe. Bankruptcy risk associated with the uncertainty regarding the ability of a company to continue operations if financial conditions owned decreased (Lesmana et al, 2003:174). Bankruptcy or financial failure occurs when the amount of the obligation exceeds the fair value of the asset or as current liabilities exceed current assets (Elmabrok et al, 2012).

\section{Altman Z-Score Model}

A business professor from New York University, USA, Edward Altman, in 1968 has developed a mathematical scoring system that predicts the possibility of bankruptcy of the company. Bankruptcy analysis conducted to obtain early warning of bankruptcy. The earlier warning proficiency level, the better for the management can immediately perform repairs. Z-Score model is a model that can be used to predict the company's financial difficulties and even bankruptcy.

The purpose of the calculation of the Z-Score is going to remind the financial problems that may require serious attention. Z-score is a score that is determined from the count standard financial ratios indicating the level of the possibility of bankruptcy of the company (Akhyar et al, 2000:136).

Altman developed a bankruptcy prediction model using five variables, with the following equation (Munawir, 2002:309) :

$$
Z=1,2 X 1+1,4 X 2+3,3 X 3+0,6 X 4+1,0 X 5
$$

Specification:

$\mathrm{X} 1=\frac{\text { WorkingCapital }}{\text { TotalAssets }}$ 


$$
\begin{aligned}
\text { X2 } & =\frac{\text { RetainedEarning }}{\text { TotalAssets }} \\
\text { X3 } & =\frac{\text { EBIT }}{\text { TotalAssets }} \\
\text { X4 } & =\frac{\text { MarketValueofEquity }}{\text { TotalLiabilities }} \\
\text { X5 } & =\frac{\text { Sales }}{\text { TotalAssets }}
\end{aligned}
$$

\section{Research Methodology}

\section{Research Design}

This research is a descriptive quantitativeresearch. The purpose of this research is to calculate Altman Z-Score to predict the possibility of bankruptcyof mining companies listed in Indonesia Stock Exchange. Time horizon in this research is crosssectional, by collecting the data in every observation year during 2014-2015.

\section{Research Population}

According Sugiyono (2010:115), Population is the generalization region consisting of object or subject that has certain qualities and characteristics defined by the researchers to be learned and then drawn conclusions. Population in this research is all of mining companies that listed in Indonesian Stock Exchange during 2014-2015.

Therefore, this research performed a census approach by using the population with certain criteria as the targeted population. Target population is a population that has been determined previously in accordance with research problem. It is aimed to obtain representative data with several criteria as follows:

1. Mining companies that provided a transparent and accessible financial report during 2014-2015.

2. Mining companies that provided the components of indicator calculations needed by the Altman ZScore model.

Based on the choosing criteria's mentioned, the total population of mining companies amount 41 companies. The mining companies that not provided financial report as much as 10 companies and there are have not needed components for Altman Z-Score derived as much as 9 companies. So, the mining companies have fulfill the criterias as much as 22 companies.

\section{Resources and Data Collection Techniques}

The data used in this research is secondary data. Secondary data refers to information gathered anyone other than the researchers who conducted this study (Sekaran, 2006:60). Secondary data generally in the form of evidence, records or historical reports that have been arranged in the archive or data published document.

Data collection techniques in this research conducted with the technical documentation. Documentation techniques is data collection by requesting data that has been there before (Djarwanto, 1990:23). Data obtained from the official website of IDX with the address www.idx.co.id.

\section{Calculating Altman Z-Score}

Altman Z-Score is calculated using the following financial ratios as follows:

\section{Working Capital to Total Assets/ WCTA(X1)}

This variable is a financial ratio is a measure of the relative net asset value of the amount of capital the company smoothly overall. This ratio illustrates the level of liquidity of a company. It can simply be interpreted as a quantitative measure of how quickly a company can convert the assets of the company consist of current and fixed assets. Working Capital which is the numerator of the ratio is the result of the difference between the company's current assets by current liabilities of the company. Thus the working capital can be interpreted as the company's ability to meet shortterm liabilities of the company at maturity.

$$
\text { WCTA }=\frac{\text { Current Assets-Current Liabilities }}{\text { Total Assets }}
$$

\section{Retained Earnings to Total Assets / RETA(X2)}

Variables retained earnings which became one of the important components in financial ratios above an account that describes the total number of the company's revenue is invested into the company. This account also represents the size of the surplus resulting from the company's operational activities as well as the company's growth opportunities in the future.

Thereby, it can simply be interpreted that this RETA ratio is a measure of cumulative profits produced by the company. This ratio also provides information on the age of the company implicitly. In general, the new company has a ratio RETA relatively lower because of the time he used to collect the profit is still too long. In addition, this ratio also measure leverage the company because of the value of the ratio can also examine the proportion of a company's assets that are financed 
using the profits it generates its own without the use of debt.

$$
\text { RETA }=\frac{\text { Retained Earnings }}{\text { Total Assets }}
$$

3. Earning Before Interest and Tax to Total Assets / EBITTA (X3)

The ratio of EBITTA as the next independent variable is a financial ratio that measures the productivity of the company's assets. EBIT the numerator of the ratio is the profit generated by the company issuing the loan interest and tax factors of calculation. EBIT is a measure of the company's revenue is generated from the company's core operations. Thus, the value of the ratio of the amount of profit that will describe the company's overall assets. The greater the ratio, the level of productivity of assets in generating revenue for the company increased.

$$
\text { EBITTA }=\frac{E B I T}{\text { Total Assets }}
$$

4. Market Value of Equity to Total Liabilities / MVETL (X4)

Financial ratios MVETL shows the magnitude of decline in the value of the company's assets that can still occur in the company before the company's liabilities exceed the value of the assets of the company in the form of common stock or preferred stock. While the cumulative liabilities from long-term liabilities and short-term liabilities. The greater the value of the ratio of MVETL describe the greater the tolerance limit of the impairment of the company's assets. That is the company that has great value ratios are relatively safer than the value of a smaller ratio. This is because the decline in the value of assets slightly in companies with a ratio of MVETL low will result in the fair value of the company's assets to be smaller than the value of liabilities of the company and lead the company into bankruptcy.

MVETL $=\frac{\text { Stock Price } \times \text { Outstanding Shares }}{\text { Total Liabilities }}$

5. Sales to Total Assets / STA (X5)

This variable is also known as capital turnover ratio and is the standard financial ratios are often done to describe the ability of the company's assets in creating sales. This ratio can be known from the management capacity to manage the assets owned in the face of competition. The greater the value of the ratio STA describe the effectiveness of management in asset management, which means lowering the probability of default of the company.

$$
\mathrm{STA}=\frac{\text { Sales }}{\text { Total Assets }}
$$

\section{Altman Model Equation}

The result of processing is used to construct discriminant equation as the equation Altman as follow:

$$
Z=1,2 \times 1+1,4 \times 2+3,3 \times 3+0,6 \times 4+1,0 \times 5
$$

\section{Descriptions:}

$\mathrm{Z}=$ Overall Index

$\mathrm{X} 1=$ Working Capital to Total Assets (WC/TA)

$\mathrm{X} 2$ = Retained Earnings to Total Assets (RE/TA)

$\mathrm{X} 3$ = Earnings Before Interest and Tax to Total Assets (EBIT/TA)

X4 = Market Value of Equity to Book Value of Debt (MVE/BVD)

$\mathrm{X} 5=$ Sales to Total Assets (S/TA)

From the results of the analysis, will get the value of $Z$ which then used as a guide to find the value of cut off. This $Z$ value can also explain the overall performance of management in view of aspects of liquidity, profitability and corporate activity.

According to (Munawir, 2002:311) the criteria of assessment could be categorized as follow:

1. If Z-Score > 2.99 is categorized as a very good company condition so it does not experience of financial difficulties.

2. If $1.81<\mathrm{Z}$-Score $<2.99$ is in a gray area so it is categorized as a company that has financial difficulties, but the possibility of bankruptcy is as big as it depends on the decision of the company management policy as the policy maker.

3. Z-Score $<1.81$ is categorized as a company that has significant financial difficulties and high risk so that the possibility of bankruptcy is very large.

\section{Research Results Research Results}

This study was aimed to calculate Altman ZScore to predict the possibility of bankruptcy of mining companies listed in IDX years 2014-2015. The assessment was conducted by using working capital to total assets ratio, retained earnings to total assets ratio, earning before interest and taxes (EBIT) to total assets 
ratio, market value of equity to total liabilities ratio and sales to total assets ratio.

\section{The Calculation Result of Altman Z-Score Year 2014}

Tabel 4.1

Calculation Result of Altman Z-Score Year 2014

\begin{tabular}{|c|l|c|c|c|c|c|c|}
\hline NO & $\begin{array}{l}\text { COMPANY } \\
\text { CODE }\end{array}$ & $\mathbf{X 1}$ & $\mathbf{X 2}$ & $\mathbf{X 3}$ & $\mathbf{X 4}$ & $\mathbf{X 5}$ & Z-Score \\
\hline 1 & ADRO & 0,092993 & 0,286136 & 0,165487 & 0,242645 & 0,518477 & 1,305738 \\
\hline 2 & ARII & $-0,35067$ & $-0,15932$ & $-0,29226$ & 0,062944 & 0,113425 & $-0,62588$ \\
\hline 3 & BYAN & $-0,20201$ & $-0,10946$ & $-0,56916$ & 0,00177 & 0,712999 & $-0,16586$ \\
\hline 4 & DEWA & 0,155674 & $-0,38696$ & 0,058717 & 0,119552 & 0,65943 & 0,606408 \\
\hline 5 & DOID & 0,231702 & $-0,11821$ & 0,098796 & 0,108437 & 0,670963 & 0,991691 \\
\hline 6 & GEMS & 0,294038 & 0,114462 & 0,156237 & 0,118441 & 1,322245 & 2,005423 \\
\hline 7 & HRUM & 0,54686 & 0,485982 & 0,054702 & 1,740492 & 1,075516 & 3,903551 \\
\hline 8 & ITMG & 0,188519 & 0,541543 & 0,661415 & 0,791301 & 1,485951 & 3,668729 \\
\hline 9 & KKGI & 0,194789 & 1,251194 & 0,423252 & 0,072623 & 1,36355 & 3,305409 \\
\hline 10 & MBAP & 0,18784 & 0,347536 & 0,720358 & 0,923135 & 1,602081 & 3,780951 \\
\hline 11 & PKPK & 0,123686 & 0,146677 & $-0,4146$ & 0,076912 & 0,251949 & 0,184624 \\
\hline 12 & PTBA & 0,311315 & 0,870074 & 0,595908 & 1,013649 & 0,882929 & 3,673874 \\
\hline 13 & PTRO & 0,17784 & 0,477177 & 0,155252 & 0,02289 & 0,743947 & 1,577107 \\
\hline 14 & TOBA & 0,120047 & 0,128111 & 0,591666 & 0,009256 & 1,663169 & 2,512249 \\
\hline 15 & ARTI & 0,17148 & $-0,09137$ & 0,049491 & 0,093426 & 0,201597 & 0,424626 \\
\hline 16 & ELSA & 0,242605 & 0,458421 & 0,435031 & 3,481631 & 0,994222 & 5,611909 \\
\hline 17 & ESSA & 0,08484 & 0,418052 & 0,933395 & 0,705143 & 0,285585 & 2,427015 \\
\hline 18 & ANTM & 0,109078 & 0,691659 & $-0,12472$ & 0,335166 & 0,427352 & 1,438535 \\
\hline 19 & CITA & 0,166626 & 0,442583 & $-0,45061$ & 0,00000492 & 0,060168 & 0,218768 \\
\hline 20 & CKRA & 0,286216 & $-0,3812$ & $-2,65778$ & 0,07154 & 0,029573 & $-2,65165$ \\
\hline 21 & INCO & 0,212345 & 0,822406 & 0,116351 & 1,185436 & 0,444729 & 2,781267 \\
\hline 22 & CTTH & 0,071835 & $-1,72542$ & 0,005806 & 0,006189 & 0,563377 & $-1,07821$ \\
\hline
\end{tabular}

Source : Data Processed (2017)

Based on Table 4.1, there are 12 mining companies that have $\mathrm{Z}$-score value $<1.81$ or according to cut-off points of Altman Z-score the companies in bankrupt condition. And there are 4 companies in the grey area with cut-off points $>1.81$ and $<2.99$ which is an area in Z-score calculation where the company has risk of financial difficulties that can lead to bankruptcy if not done improvement of company performance. In 2014 , there were 6 companies that have cut-off points $>2.99$ where these companies are in a healthy financial condition or do not go bankrupt. The financial condition of mining companies in 2014 can be seen in Table 4.2 as follows.

Table 4.2

Bankruptcy Prediction of Mining Companies Year 2014

\begin{tabular}{|l|l|c|c|}
\hline \multirow{2}{*}{ NO. } & \multicolumn{1}{|c|}{ COMPANY NAME } & Z-SCORE & LEVEL \\
\hline 1 & Adaro Energy Tbk & 1,305738 & Bankrupt \\
\hline 2 & Atlas Resources Tbk & $-0,62588$ & Bankrupt \\
\hline 3 & Bayan Resources Tbk & $-0,16586$ & Bankrupt \\
\hline
\end{tabular}




\begin{tabular}{|l|l|c|c|}
\hline NO. & \multicolumn{1}{|c|}{ COMPANY NAME } & Z-SCORE & LEVEL \\
\hline 4 & Darma Henwa Tbk & 0,606408 & Bankrupt \\
\hline 5 & Delta Dunia Makmur Tbk & 0,991691 & Bankrupt \\
\hline 6 & Golden Energy Mines Tbk & 2,005423 & Grey Area \\
\hline 7 & Harum Energy Tbk & 3,903551 & Not Bankrupt \\
\hline 8 & Indo Tambangraya Megah Tbk & 3,668729 & Not Bankrupt \\
\hline 9 & Resource Alam Indonesia Tbk & 3,305409 & Not Bankrupt \\
\hline 10 & PT Mitrabara Adiperdana Tbk & 3,780951 & Bankrupt \\
\hline 11 & Perdana Karya Perkasa Tbk & 0,184624 & Bankrupt \\
\hline 12 & Tambang Batubara Bukit Asam Tbk & 3,673874 & Grey Area \\
\hline 13 & Petrosea Tbk & 1,577107 & Bankrupt \\
\hline 14 & Toba Bara Sejahtra Tbk & 2,512249 & Not Bankrupt \\
\hline 15 & Ratu Prabu Energi Tbk & 0,424626 & Grey Area \\
\hline 16 & Elnusa Tbk & 5,611909 & Bankrupt \\
\hline 17 & Surya Esa Perkasa Tbk & 2,427015 & Bankrupt \\
\hline 18 & Aneka Tambang Tbk & 1,438535 & Grey Area \\
\hline 19 & Cita Mineral Investindo Tbk & 0,218768 & Bankrupt \\
\hline 20 & Cakra Mineral Tbk & $-2,65165$ & 2,781267 \\
\hline 21 & Vale Indonesia Tbk & $-1,07821$ & \\
\hline 22 & Citatah Tbk & & \\
\hline
\end{tabular}

Source : Data Processed (2017)

Calculation Result of Altman Z-Score Year 2015

Tabel 4.3

Calculation Result of Altman Z-Score Year 2015

\begin{tabular}{|l|l|c|c|c|c|c|c|}
\hline NO & $\begin{array}{l}\text { COMPANY } \\
\text { CODE }\end{array}$ & $\mathbf{X 1}$ & $\mathbf{X 2}$ & $\mathbf{X 3}$ & $\mathbf{X 4}$ & $\mathbf{X 5}$ & Z-Score \\
\hline 1 & ADRO & 0,128495 & 0,325882 & 0,155054 & 0,102447 & 0,450519 & 1,162398 \\
\hline 2 & ARII & $-0,53075$ & $-0,25108$ & $-0,24883$ & 0,001944 & 0,080635 & $-0,94808$ \\
\hline 3 & BYAN & 0,16918 & $-0,23219$ & $-0,23991$ & 0,000842 & 0,495822 & 0,193741 \\
\hline 4 & DEWA & 0,087657 & $-0,36035$ & 0,04807 & 0,060546 & 0,643807 & 0,479733 \\
\hline 5 & DOID & 0,296199 & $-0,15349$ & $-0,02297$ & 0,010248 & 0,679993 & 0,809981 \\
\hline 6 & GEMS & 0,408006 & 0,099012 & 0,014926 & 1,868662 & 0,955416 & 3,346022 \\
\hline 7 & HRUM & 0,607923 & 0,495939 & $-0,15336$ & 0,213042 & 0,655001 & 1,818544 \\
\hline 8 & ITMG & 0,23216 & 0,525662 & 0,390518 & 0,304021 & 1,348828 & 2,801188 \\
\hline 9 & KKGI & 0,258328 & 1,345292 & 0,304242 & 0,018156 & 1,126545 & 3,052564 \\
\hline 10 & MBAP & 0,390414 & 0,610876 & 1,432375 & 0,052988 & 2,007214 & 4,493866 \\
\hline 11 & PKPK & 0,039421 & 0,047649 & $-0,52578$ & 0,013609 & 0,0878 & $-0,3373$ \\
\hline 12 & PTBA & 0,190061 & 0,844586 & 0,520333 & 0,337657 & 0,812927 & 2,705565 \\
\hline 13 & PTRO & 0,159235 & 0,498812 & 0,030751 & 0,004556 & 0,257032 & 0,950385 \\
\hline 14 & TOBA & 0,059072 & 0,154756 & 0,176374 & 0,001325 & 0,389029 & 0,780555 \\
\hline 15 & ARTI & 0,115727 & $-0,07204$ & 0,021196 & 1,59261 & 0,08379 & 1,741279 \\
\hline 16 & ELSA & 0,171725 & 0,476755 & 0,38411 & 0,71653 & 0,856565 & 2,605685 \\
\hline
\end{tabular}




\begin{tabular}{|l|l|c|c|c|c|c|c|}
\hline 17 & ESSA & 0,108368 & 0,235923 & 1,125422 & 0,041344 & 0,145765 & 1,656822 \\
\hline 18 & ANTM & 0,292122 & 0,442413 & $-0,18141$ & 0,187913 & 0,346924 & 1,087964 \\
\hline 19 & CITA & $-0,09926$ & 0,286079 & $-0,40275$ & 0,00015 & 0,004973 & $-0,21081$ \\
\hline 20 & CKRA & 0,288053 & $-0,08105$ & $-5,60427$ & 0,232977 & 0,022492 & $-5,1418$ \\
\hline 21 & INCO & 0,236661 & 0,868308 & 0,289798 & 0,415077 & 0,344993 & 2,154837 \\
\hline 22 & CTTH & 0,296034 & $-1,02758$ & 0,021729 & 0,008064 & 0,364471 & $-0,33728$ \\
\hline
\end{tabular}

Source : Data Processed (2017)

Based on Table 4.3, it can be seen that there are 14 mining companies that are in bankruptcy by 2015 . And as many as 5 companies are in grey area, while the other 3 companies have good financial condition or not bankrupt. These conditions can be seen in Table 4.4 as follows.

Table 4.4

Bankruptcy Prediction of Mining Companies Year 2015

\begin{tabular}{|c|l|l|l|}
\hline NO. & COMPANY NAME & Z-SCORE & LEVEL \\
\hline 1 & Adaro Energy Tbk & 1,162398 & Bankrupt \\
\hline 2 & Atlas Resources Tbk & $-0,94808$ & Bankrupt \\
\hline 3 & Bayan Resources Tbk & 0,193741 & Bankrupt \\
\hline 4 & Darma Henwa Tbk & 0,479733 & Bankrupt \\
\hline 5 & Delta Dunia Makmur Tbk & 0,809981 & Bankrupt \\
\hline 6 & Golden Energy Mines Tbk & 3,346022 & Not Bankrupt \\
\hline 7 & Harum Energy Tbk & 1,818544 & Grey Area \\
\hline 8 & Indo Tambangraya Megah Tbk & 2,801188 & Grey Area \\
\hline 9 & Resource Alam Indonesia Tbk & 3,052564 & Not Bankrupt \\
\hline 10 & PT Mitrabara Adiperdana Tbk & 4,493866 & Not Bankrupt \\
\hline 11 & Perdana Karya Perkasa Tbk & $-0,3373$ & Bankrupt \\
\hline 12 & Tambang Batubara Bukit Asam Tbk & 2,705565 & Grey Area \\
\hline 13 & Petrosea Tbk & 0,950385 & Bankrupt \\
\hline 14 & Toba Bara Sejahtra Tbk & 0,780555 & Bankrupt \\
\hline 15 & Ratu Prabu Energi Tbk & 1,741279 & Bankrupt \\
\hline 16 & Elnusa Tbk & 2,605685 & Grey Area \\
\hline 17 & Surya Esa Perkasa Tbk & 1,656822 & Bankrupt \\
\hline 18 & Aneka Tambang Tbk & 1,087964 & Bankrupt \\
\hline 19 & Cita Mineral Investindo Tbk & $-0,21081$ & Bankrupt \\
\hline 20 & Cakra Mineral Tbk & $-5,1418$ & Bankrupt \\
\hline 21 & Vale Indonesia Tbk & 2,154837 & Grey Area \\
\hline 22 & Citatah Tbk & $-0,33728$ & Bankrupt \\
\hline
\end{tabular}

Source : Data Processed (2017)

Based on Table 4.4, it can be seen that by 2015 most mining companies are in a state of bankruptcy. From a total of 22 mining companies, only 3 companies that have a financial situation that is really healthy or not bankrupt.
With the difficult financial condition, management should be able to make improvements to prevent companies are in a worse position. By 2015, there are several mining companies that are able to improve their financial condition which in the previous 
year was in bankrupt condition, then in the next year in the gray area. Here Table 4.5 which will show the financial condition of mining companies in 2014 and 2015.

Table 4.5

Bankruptcy Prediction of Mining Companies Year 2014-2015

\begin{tabular}{|c|c|c|c|}
\hline NO. & COMPANY NAME & 2014 & 2015 \\
\hline 1 & Adaro Energy Tbk & Bankrupt & Bankrupt \\
\hline 2 & Atlas Resources Tbk & Bankrupt & Bankrupt \\
\hline 3 & Bayan Resources Tbk & Bankrupt & Bankrupt \\
\hline 4 & Darma Henwa Tbk & Bankrupt & Bankrupt \\
\hline 5 & Delta Dunia Makmur Tbk & Bankrupt & Bankrupt \\
\hline 6 & Golden Energy Mines Tbk & Grey Area & Not Bankrupt \\
\hline 7 & Harum Energy Tbk & Not Bankrupt & Grey Area \\
\hline 8 & Indo Tambangraya Megah Tbk & Not Bankrupt & Grey Area \\
\hline 9 & Resource Alam Indonesia Tbk & Not Bankrupt & Not Bankrupt \\
\hline 10 & PT Mitrabara Adiperdana Tbk & Not Bankrupt & Not Bankrupt \\
\hline 11 & Perdana Karya Perkasa Tbk & Bankrupt & Bankrupt \\
\hline 12 & Tambang Batubara Bukit Asam Tbk & Not Bankrupt & Grey Area \\
\hline 13 & Petrosea Tbk & Bankrupt & Bankrupt \\
\hline 14 & Toba Bara Sejahtra Tbk & Grey Area & Bankrupt \\
\hline 15 & Ratu Prabu Energi Tbk & Bankrupt & Bankrupt \\
\hline 16 & Elnusa Tbk & Not Bankrupt & Grey Area \\
\hline 17 & Surya Esa Perkasa Tbk & Grey Area & Bankrupt \\
\hline 18 & Aneka Tambang Tbk & Bankrupt & Bankrupt \\
\hline 19 & Cita Mineral Investindo Tbk & Bankrupt & Bankrupt \\
\hline 20 & Cakra Mineral Tbk & Bankrupt & Bankrupt \\
\hline 21 & Vale Indonesia Tbk & Grey Area & Grey Area \\
\hline 22 & Citatah Tbk & Bankrupt & Bankrupt \\
\hline
\end{tabular}

Source : Data Processed (2017)

Based on table 4.5 can be seen that in 2015 the number of bankruptcies of mining companies increased from the previous year, which in 2014 there are 12 companies that went bankrupt, then in 2015 increased to 14 companies. Similarly, companies in the gray area also increased from the previous year. And just the opposite, the decline occurred in companies in 2014 belonging to the healthy category of 6 companies but in 2015 decreased to 3 companies.

Based on the condition of mining company above, it can be presented as seen in Table 4.6 as follows.

Table 4.6

Percentage of Bankruptcy Prediction of Mining Companies Year 2014-2015

\begin{tabular}{|l|c|c|}
\hline BANKRUPTCY PREDICTION & $\mathbf{2 0 1 4}$ & $\mathbf{2 0 1 5}$ \\
\hline Bankrupt & $55 \%$ & $64 \%$ \\
\hline Grey Area & $18 \%$ & $23 \%$ \\
\hline Not Bankrupt & $27 \%$ & $13 \%$ \\
\hline
\end{tabular}


According to Table 4.6 can be seen that the bankruptcy prediction in mining companies have conditions that are getting worse every year. The prediction of bankruptcies experienced by mining companies from 2014 is $55 \%$, increasing by 2015 to $64 \%$. While in the grey area in 2014 by $18 \%$ increased to $23 \%$. And there is a decline in the company that is not bankrupt which in 2014 by $27 \%$, then in 2015 to $13 \%$.

\section{CONCLUSIONS}

Based on the discussion in the previous chapters, this research was aimed to findout Altman ZScore to predict the possibility of bankruptcy of mining companies. The conclusion of this research is that 12 mining companies in 2014 are in bankrupt condition or about $55 \%$. And there are 4 companies $(18 \%)$ are in the gray area, while 6 more companies (27\%) are in healthy condition or not bankrupt. In 2015, bankruptcy predictions in mining companies resulted in $13 \%$ of companies in healthy condition or not bankrupt, $23 \%$ are in the gray area and 64\% predicted to be in a state of bankruptcy. Opportunity bankruptcy is of course will be greater if the management company does not immediately conduct an evaluation of the company's financial condition. In addition, every improvement required by the company to reduce the possibility of bankruptcy.

\section{REFERENCES}

Akhyar, Muhammad Adnan dan Eha Kurniasih. 2000. Analisis Tingkat Kesehatan Perusahaan untuk Memprediksi Potensi Kebangkrutan dengan Pendekatan Altman. Jurnal Akuntansi dan Auditing Indonesia. Vol. 4 No. 2, hal 131-151. Yogyakarta: Fakultas Ekonomi Universitas Islam Indonesia.

Altman, Edward I., 1968. Financial Ratios, Discriminant Analysis and the Prediction of Corporate Bankruptcy. The Journal of Finance. Vol. XXIII No. 4. p. 589-609.

Atmini, S dan Wuryana. 2005. Manfaat Laba dan Arus Kas untuk Memprediksi Kondisi Financial Distress pada Perusahaan Textile Mill Products dan Appareal and other Textile Products yang
Terdaftar di Bursa Efek Jakarta. Simposium Nasional Akuntansi VIII: hal 460-477.

Brealey et al. 2008. Dasar-Dasar Manajemen Keuangan Perusahaan. Jakarta: Erlangga.

Brigham, Eugene F. and Joel F. Houston. 2006. Dasar-Dasar Manajemen Keuangan. Book 1. $10^{\text {th }}$ Ed. Translate by Ali Akbar Yulianto. Jakarta: PT. Salemba Empat.

Djarwanto . 1990. Pokok-Pokok Analisa Laporan Keuangan. Edisi Pertama. Cetakan Kedelapan. Yogyakarta: BPFE

Elmabrok, Ali Abusalah., Mohammed \& Ng KimSoon. 2012. Using Altman's Model and Current Ratio to Assess the Financial Status of Companies Quoted In the Malaysian Stock Exchange. International Journal of Scientific and Research Publications, 2(7). Faculty of Technology Management, Business and Entrepreneurship, Universiti Tun Hussein Onn Malaysia.

Endri. Prediksi Kebangkrutan Bank untuk Menghadapi dan Mengelola Perubahan Lingkungan Bisnis: Analisis Model Altman Z-Score. Jurnal Ekonomi dan Bisnis. ISSN, 1078-9017. 2009.

Grice, J.S and R.W. Ingram. 2001. Test of The Generalizability of Altman's Bankruptcy Prediction Model. Journal of Business Research 54 (2001) 53-61.

Hanafi, Mamduh M dan Abdul Halim. 2005. Analisis Laporan Keuangan. Edisi Revisi. Yogyakarta: AMP YKPN.

Hanafi, Mamduh M. 2004. Manajemen Keuangan. Edisi I. Yogyakarta: BPFE.

Harnanto. 1984. Analisis Laporan Keuangan. Yogyakarta: UPP AMP YKPN.

Jauch, Lawrence dan W. Gleuck. 1995. Manajemen Strategi dan Kebijaksanaan Perusahaan. Edisi Ketiga. Jakarta: Erlangga.

Jogiyanto, Hartono. 2010. Analisis \& Desain. Yogyakarta: Penerbit Andi.

Kamal, St.Ibrah Mustafa. 2012. Analisis Prediksi Kebangkrutan pada Perusahaan Perbankan Go Public di Bursa Efek Indonesia (dengan Menggunakan Model Altman Z-Score). Skripsi. Makasar: Universitas Hasanuddin Makassar. 
Lesmana et al, 2003. Financial Performance Analyzing. Jakarta: Elex Media Komputindo.

Munawir, S. 2002. Analisa Laporan Keuangan. Yogyakarta: Liberty.

Rompon, Restmen. 2012. Analisis Kebangkrutan Mengunakan Model Z-Score Pada Perusahaan Pertambangan Yang Terdaftar Di Bursa Efek Indonesia. Skripsi. Makasar: Universitas Hasanuddin Makassar.

Sarwani dan Rasidah. 2008. Analisis Diskriminan Model Altman (Z-Score) Dalam Mengukur Kinerja Keuangan Untuk Memprediksi Kebangkrutan Pada Industri Kayu Yang Terdaftar Di Bursa Efek Jakarta.JEPMA Vol. 7, No. 2 hal. 200 - 230. Universitas Lambung Mangkurat Banjarmasin..

Sawir, Agnes. 2000. Analisis kinerja keuangan dan perencanaan keuangan perusahaan. Jakarta: PT Gramedia Pustaka Utama

Sekaran, Uma. 2006. Research Methods for Busines: Metodologi Penelitian untuk Bisnis. Buku 1. Edisi 4. Terjemahan Kwan Men Yon. Jakarta: Salemba Empat.

Setiawan, Agung. 2004. Identifikasi kondisi keuangan perusahaan dengan menggunakan Model Altman (Z-score) dan Zavren (Model Logit). Universitas Brawijaya. Skripsi.

Tambunan, Rafles W. Dwiatmanto dan Wi Endang, N.P M.G. 2015. Analisis Prediksi Kebangkrutan Perusahaan Dengan Menggunakan Metode Altman (Z-Score) (Studi Pada Subsektor Rokok Yang Listing Dan Perusahaan Delisting Di Bursa Efek Indonesia Tahun 2009 - 2013). Jurnal Administrasi Bisnis $(J A B) \mid$ Vol. 2 No. 1. Malang: Universitas Brawijaya.

Tristantyo, Yoga Rhesana. 2012. Analisis Model Altman Z-Score dalam memprediksi kebangkrutan pada perusahaan perbankan swasta nasional devisa yang go publik di bei. Skripsi. Universitas Widyatama.

https://www.bloomberg.com/news/articles/2017-01-

26/china-sees-graying-generation-as-quarter-ofpopulation-by-2030

http://www.nasdaq.com/markets/crude-oil.aspx http://www.usatoday.com/story/money/2016/04/12/im f-cuts-global-forecast-backs-urgentaction/82921118/ https://www.washingtonpost.com/news/energyenvironment/wp/2016/04/13/coal-titan-peabodyenergy-files-for-bankruptcy/ 